\title{
Control of Fetal Development in the Female Black Sea Bottlenose Dolphin (Tursiops Truncates Ponticus Barabash, 1940) using Ultrasound Procedure and Studying the Dynamics of the Linear Dimensions of the Fetal Head.
}

\author{
Semenov V.A., Rodin I.A., Okolelova A.I., Vinokurova D.P., Gavrilov B.V.
}

\begin{abstract}
Control of fetal development in the female Black Sea bottlenose dolphin (Tursiops truncates ponticus Barabash, 1940) using ultrasound procedure and studying the dynamics of the linear dimensions of the fetal head. The use of the method of ultrasound diagnosis is relevant for determining the pregnancy of Black Sea bottlenose dolphins, its timing and monitoring the development of the fetus. At the same time, hematological parameters of pregnant females provide an objective assessment of the probability of physiologically normal delivery.

Keywords: pregnancy, ultrasound procedure, hematological parameters, black sea bottlenose dolphin.

Abbreviations: ALT - Alanine Transaminase, ALP - alkaline phosphatase.
\end{abstract}

\section{INTRODUCTION}

Pregnancy is an important period in the life of mammals, including cetaceans, held in captivity. Of course, this allows them to draw attention to the nutritional characteristics of animals. Therefore, timely diagnosis of pregnancy, the establishment of a period and the development of embryos in various periods of prenatal ontogenesis are extremely important (Shantiz A.U., 1999).

The gestation period for bottlenose dolphins lasts approximately $12 \pm 1$ months. For example, in the Indian bottlenose dolphin (T.t. Aduncus) with known dates of conception, a period of $370 \pm 11$ days is determined (Brook, 1997). The lactation period in bottlenose dolphins can last up to 2 years and even more in wild animals. (Robeck T.R. e. A., 2001). Most females first produce calves between the ages of 7 and 10 years (Duffield et al., 2000). The full reproductive cycle or period of time between births is 3-4 years. The duration of the estrous cycle in $T$. truncatus is 21 to 42 days (Sawyer-Steffan and Kirby, 1980; Kirby and Ridgway, 1984; Schroeder, 1990).

Revised Manuscript Received on January 03, 2020.

* Correspondence Author St., Gelendzhik, Krasnodar Territory, 353460, Russia

Rodin I.A., Kuban State Agrarian University named after I.T. Trubilina, 13 Kalinina St., Krasnodar, Krasnodar Territory, 350044, Russia

Okolelova A.I., Kuban State Agrarian University named after I.T. Trubilina, 13 Kalinina St., Krasnodar, Krasnodar Territory, 350044, Russia

Vinokurova D.P., Kuban State Agrarian University named after I.T. Trubilina, 13 Kalinina St., Krasnodar, Krasnodar Territory, 350044, Russia

Gavrilov B.V., Kuban State Agrarian University named after I.T. Trubilina, 13 Kalinina St., Krasnodar, Krasnodar Territory, 350044, Russia

(C) The Authors. Published by Blue Eyes Intelligence Engineering and Sciences Publication (BEIESP). This is an open access article under the CC BY-NC-ND license (http://creativecommons.org/licenses/by-nc-nd/4.0/)
Semenov V.A.*, (CJSC) Gelendzhiky Dolphinarium, 130 Lunacharsky

All cetaceans are single-birth animals, in which cases of multiple-birth are very rare and range from $0.002 \%$ in finwala(Balaenoptera physalus) to $0.5 \%$ in beluga whales (Delphinapterus leucas). A positive evolutionarily acquired trait, and rare cases of multiple pregnancy are classified as atavistic traits (Yablokov A.V. et al., 1972). According to available data (Ozharovskaya, 1997) about numerous cases of childbirth in female captive bottlenose dolphins in captivity, all of them ended with the birth of one cub. Only two cases of double pregnancy are mentioned in the literature. Not one of them had a successful outcome. In one case, the twins were born dead (Ridgwey, Benirschke, 1977); in another, the female had premature birth and, four months after her death, at dissection, a full-term macerated fetus was found in her (Gray and Conclin, 1974).

The only, well-developed cub is born very large - from $1 / 4$ to $1 / 2$ the length of the mother's body. Occasionally, several embryos are found in one female. Seven were once found in a blue whale, and six embryos in a finwal and a saival. This is evidence of the past multiple years of cetacean ancestors. Extra embryos usually resolve, and very rarely can twins be born (Tomilin A.G., 1957). The death of one of the embryos in humans can lead to serious health problems of the second or even its death. According to statistics, in the event of the death of one of the embryos in the first third of pregnancy, the probability of normal development and birth of the second reaches $90 \%$. In this case, the embryo is completely resorbed or softened. If the death of one fetus with twins occurred at a later date, then the second may develop severe damage to the central nervous system, internal organs or death (Tsivtsivadze E.B., Novikova S.V., 2014).

Reproductive function in dolphins, as in other mammals, is regulated by a number of neurological and hormonal feedback mechanisms, involving the hypothalamus, pituitary, and sex glands in this process. These three organs are commonly called the hypothalamicpituitary-gonadal system (Aubin 2001).

The effect of various environmental factors on the reproductive cycle indicates that the reproduction process is under the control of nerve stimuli transmitted to the brain. The main part of the transmission and transformation of these stimuli appears to occur in the hypothalamus and its

Published By:

Blue Eyes Intelligence Engineering

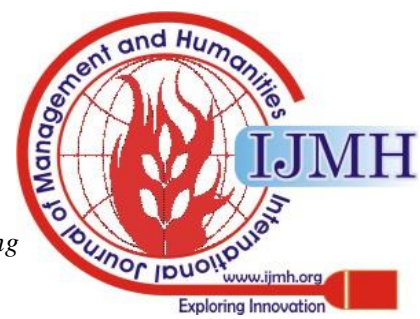


associated nuclei, the neurons of which secrete cryotropic hormones into the portal pituitary system (Robeck T.R. e. A., 2001). These hormones control the anterior pituitary gland, or adenohypophysis. Among such neurohormones is gonadotropin-releasing hormone (GnRH), which is of paramount importance for the regulation of the endocrine aspects of mammalian reproduction. Activation of GnRHreceptors in the anterior pituitary gland secretes luteinizing hormone (LH) and follicle-stimulating hormone (FSH) into the bloodstream. As the follicle grows and ripens, estrogen is produced due to the paracrine interaction between the cells of the inner membrane (theca interna) of the follicle and the granular layer (granulose) lining the follicle.

Initially, an increase in estrogen synthesis inhibits both LH and FSH secretion in the pituitary gland. As the maturing follicle approaches the preovulatory stage, estrogens that have reached the maximum level of secretion begin to have a positive inverse effect on the frequency and amplitude of $\mathrm{GnRH}$ emissions, which in turn leads to preovulatory LH release. LH stimulates the formation of a low molecular weight glycoprotein, the so-called inhibin, in the follicle. Inhibin not only inhibits FSH secretion, but also increases the sensitivity of theca interna cells of the preovulatory follicle to LH (Baird and Smith, 1993). This combination of increasing the number of LH receptors and increasing sensitivity to $\mathrm{LH}$ provides an appropriate response to $\mathrm{LH}$ release and ovulation.

After ovulation, granular and parietal cells are converted into large progesterone-secreting and small luteal cells, respectively (Hendricks 1991). Progesterone, and to a lesser extent estrogen, produced by the corpus luteum, suppress luteinizing and follicle-stimulating hormones, released from the hypothalamus.

Therefore, until recently, the level of plasma progesterone was the most common criterion for pregnancy in females of the Black Sea bottlenose dolphins. Some authors consider this indicator a reliable diagnostic criterion if the level of progesterone in three consecutive samples with a 2-week break is higher than $3 \mathrm{ng} / \mathrm{ml}$. (Schroeder 1990, Robeck et al. 2001). Unfortunately, in practice there are cases of pseudopregnancy, the causes of which are unknown to dolphins and can be numerous. In these cases, pregnancy cannot be confirmed without the use of ultrasound. The use of ultrasound to monitor pregnancy in captive cetaceans provides valuable data on the morphology, development, and well-being of the fetus. When examining the fetus, measurements of the chest and head are important, since they can play an important role in determining the gestational age of bottlenose dolphins (Williamson P., et al, 1990; Stone LR, EA, 1999; Semenov VA. Et al., 2016; Busharova E.V., 2011), however, as with other mammals, including humans (Medvedev M.V., 2005). Until 2008 (V. Semenov et al., 2008) in the territory of the Russian Federation, single attempts at ultrasound examination of Tursiopstruncatusponticus by practitioners on the Black Sea coast were not always successful, were not described in the literature and did not have a systemic character.

Assessment of the size of the chest and head are an important part of the examination of the fetus in dynamics to control its proper development. For example, due to the reducing the level of gonadotropin-releasing hormone

underdevelopment of the bone skeleton of the chest, lung hypoplasia can occur, which in turn can cause perinatal mortality in humans (Serov V. e.a., 1997; Saveliev, GM, 1998). At the same time, with reduced values of the diameter of the head, especially during full-term pregnancy, intrauterine growth retardation syndrome is often diagnosed, usually due to reduced utero-placental blood flow (Saveliev, GM E.A., 1991; Strizhakov AN, e.a. , 2004).

Female bottlenose dolphins kept in Atlantis Marine Park (Western Australia) used B-mode ultrasound to diagnose pregnancy and measure the growing fetus (Williamson et al. 1990). Examinations were performed at approximately a monthly interval using an AlokaSSD260 ultrasound machine (Aloka, Tokyo, Japan) with a linear sensor at a frequency of 33-5 MHz (AlokaUST-5021). The converter was enclosed in a thin plastic bag (to protect against contact with salt water) and provided with a large amount of gel to ensure good contact with the object. Measurements of the cross section of the chest were taken at the level of the 2nd or 3rd intercostal space, the diameter of the skull, the width of the ribs and cervical vertebrae, as well as the length of the rostrum. Due to the short duration of the imaging process, proper images of the chest and the diameter of the skull (occipital-frontal axis) were obtained, images of the remaining structures of the fetus did not give reliable results. Sizing of the fetal structures was carried out by comparing them with a scale on the screen of the ultrasound apparatus. As a result of research, a linear dependence of an increase in the parameters of a developing fetus was revealed. The fetal heartbeat was regularly visualized and indicated fetal viability.

Particular interest are studies of the growth dynamics of the head and chest of the fetus in females with successful delivery on the one hand, and unsuccessful childbirth on the other.

\section{RESEARCH METHODOLOGY}

The purpose of these studies was to detect pregnancy in female bottlenose dolphins (TursiopstruncatusponticusBarabash, 1940) using ultrasound examination and to study the dynamics of the linear dimensions of the fetal head, as well as blood tests of pregnant females, depending on its timing in cases of successful and unsuccessful delivery.

In the period from 2009 to 2018, we identified 33 cases of pregnancy of the Black Sea bottlenose dolphins in 13 females aged 6.5 to 23 years in various dolphinariums on the Black Sea coast and 143 studies were conducted. Due to the lack of experience in conducting an ultrasound examination of the Black Sea dolphins at the initial stages of studying this issue, not all studies turned out to be correct and reliable, therefore only 100 of them were included in this work and underwent biometric processing. The length of the animals varied from 240 to $275 \mathrm{~cm}$, and the weight during the absence of pregnancy or in its initial stage ranged from 172 to $283 \mathrm{~kg}$.

Blue Eyes Intelligence Engineering

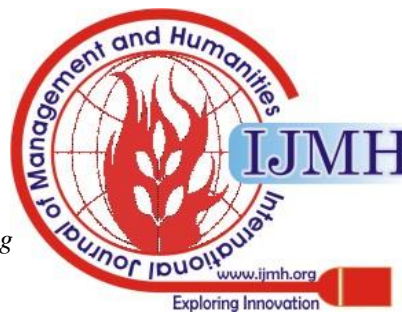


Pregnant animals require particularly gentle treatment of themselves, eliminating negative emotions that could harm the health of the mother and fetus. Therefore, the female during the examination was not taken out of the water, but was examined at the side of the pool in a lateral lying position, which allowed her to raise her head above the water level at any time and make an unhindered act of exhalation-inspiration.

In addition, dolphins hear ultrasounds very well, published by themselves in the water, as well as their reflections, which easily penetrate the body of these animals and reach the inner ear (Yablokov A.V., 1972). Therefore, it takes some time, perhaps several sessions with food reinforcement, so that the dolphin gets used to the ultrasound emitted by the sensor of the ultrasound apparatus, and at the same time does not show concern. These studies were focused on the detection of pregnancy of females using ultrasound examination and the study of the dynamics of the dorso-ventral (upper-lower) sizes of the fetal head and chest in the sagittal plane at different stages of pregnancy. The head was measured along the contours of the bones, and the chest - taking into account the soft tissues at the level of the heart. Pregnancy was established retrospectively from the date of birth.

All 33 pregnancy cases were divided into two groups:

1) ended with a successful delivery;

2) ended in unsuccessful delivery, characterized by the birth of stillborn cubs or who died on the first day after birth.

Biometric processing of measurements of the fetus, as well as the results of blood tests of females during pregnancy, was carried out both as a whole in all cases of research, and separately in each group. Ultrasound examination of pregnant females was carried out using a SonoSite180 apparatus manufactured in the USA with a penetration depth of ultrasonic waves of up to $22 \mathrm{~cm}$ and a C60 / 5 - $2 \mathrm{MHz}$ convex transducer. Blood samples for testing was taken from the tail veins- Superficial fluke $v \mathrm{v}$ (Bossart GD, 2001). In this case, a clinical blood test was performed on a "Cell-Dyn" automated analyzer (Abbott USA) using Abbott USA test systems - a general blood test, biochemical studies were performed on an ARCHITECT C8000 automatic analyzer (Abbott USA) using a test Abbott USA systems - biochemistry, the concentration of progesterone in the blood was determined using an Architect i2000 automated analyzer (Abbott USA) using Abbott USA test systems - hormones.

\section{RESULTS AND FINDINGS}

In our studies, pregnancy in all cases ended with delivery through the natural birth canal. The level of plasma progesterone during pregnancy ranged from 1.70 to 120.0 $\mathrm{ng} / \mathrm{ml}$ and was on average $24.0 \pm 2.03 \mathrm{ng} / \mathrm{ml}$ (the number of studies was 82), while in the absence of pregnancy it was significantly lower $(\mathrm{P}<0.001)$, varying from 0 to 17.1 $\mathrm{ng} / \mathrm{ml}$, and was on average $2.1 \pm 0.39 \mathrm{ng} / \mathrm{ml}$ (the number of studies was 74). During the second half of pregnancy, fetal heart rate was recorded in all pregnant females from 120 beats per minute at the 6th month and 117 beats per minute at the 7th month to 96 beats per minute at the beginning of the 12 th month, and then up to 76 at the end 12th month 5 days before birth.
We managed to fix the earliest stage of pregnancy in a female bottlenose dolphin using ultrasound examination at the 2nd month of its existence (Figure 1). The level of progesterone in her blood at the time of the study was 7.58 $\mathrm{ng} / \mathrm{ml}$. A fetal egg with a maximum upper-lower size of 7.02 $\mathrm{cm}$ was implanted in the right uterine horn. The figure shows that the hypoechoic myometrium of the uterus is lined with hyperechoic endometrium from the inside. The endometrium limits the anechogenic cavity of the chorion, in the ventral part of which the hyperechoic structure of the embryo is detected.

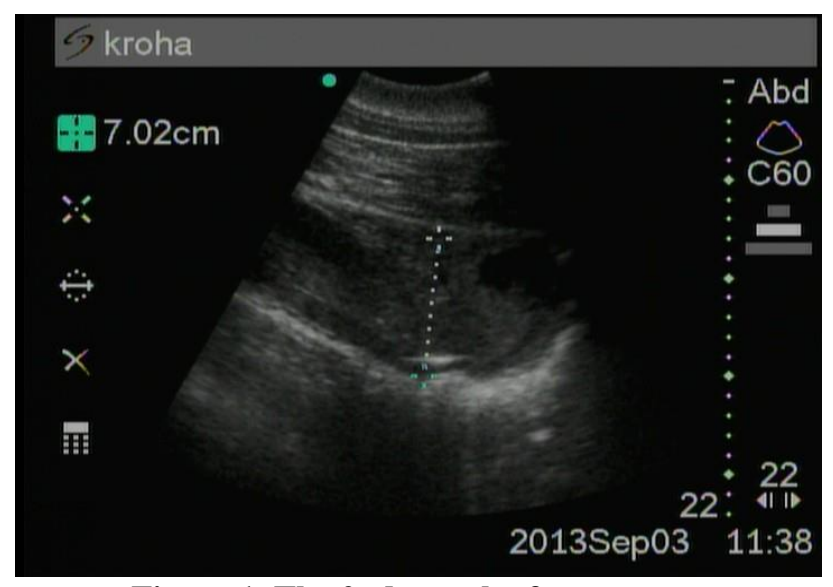

Figure 1. The 2nd month of pregnancy

At the 3rd month of pregnancy (Figure 2), the fetal egg has an upper-lower size of at least $10 \mathrm{~cm}$ and is even more elongated. We see that the fetus with head presentation is still small and fits entirely into the scanning sector, and its length is slightly more than $14 \mathrm{~cm}$. In this figure, the formation of the placenta, as well as the trunk, head, tail, hyperechoic spine.

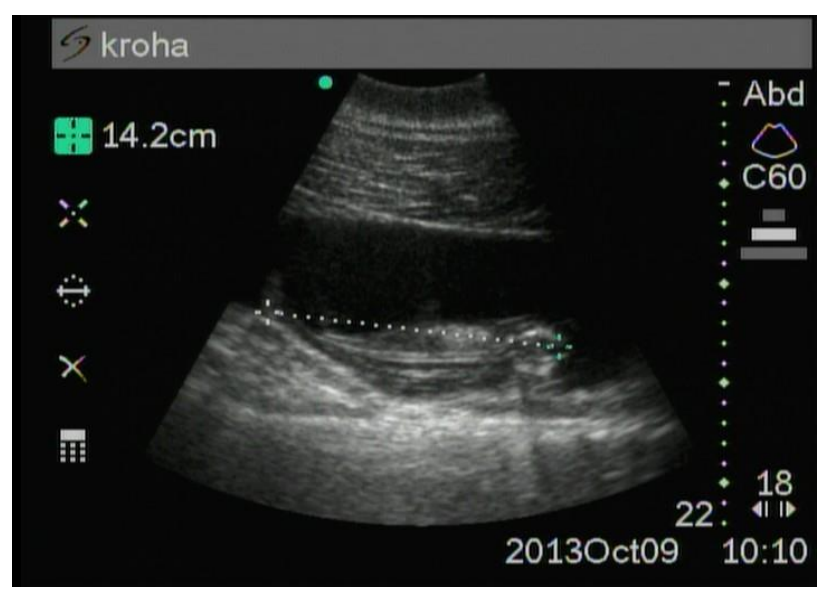

Figure 2. The 3rd month of pregnancy

The largest relative increase in the fetal head during the entire period of pregnancy occurred in the fourth month, namely, by $35.7 \%$ (per $1 \mathrm{~cm}$ ) compared with the previous, third, month. At this time, the ovum is significantly enlarged and extended, due to which we can observe a bend in the uterine horn by 1800 (Figure 3), while the upper-lower head size is on average $3.8 \pm 0.12 \mathrm{~cm}$.

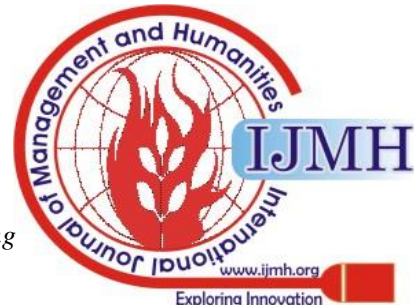


Control of Fetal Development in the Female Black Sea Bottlenose Dolphin (Tursiops Truncates Ponticus Barabash, 1940) using Ultrasound Procedure and Studying the Dynamics of the Linear Dimensions of the Fetal Head

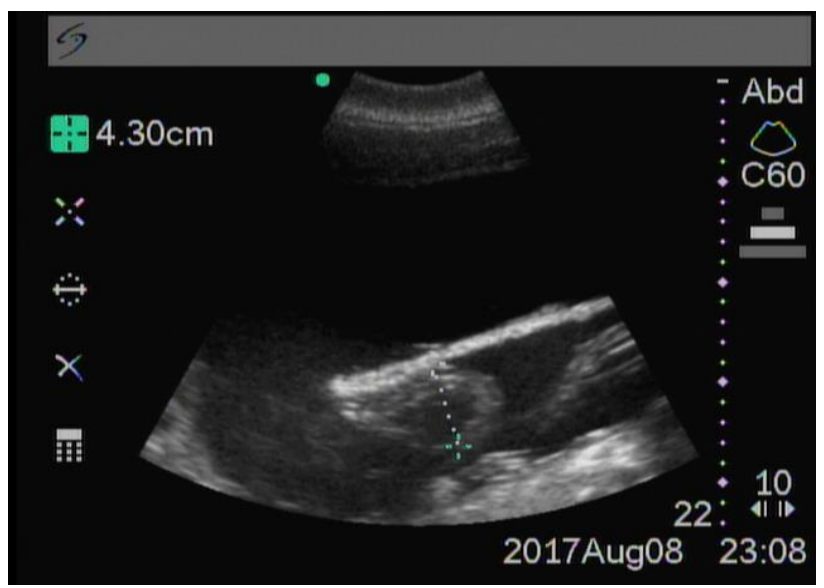

Figure 3. The 4th month of pregnancy

At the 5th month (Figure 4), the fetus actively moves in a large space of amniotic fluid, and the size of the head reaches $4.4 \pm 0.08 \mathrm{~cm}$.

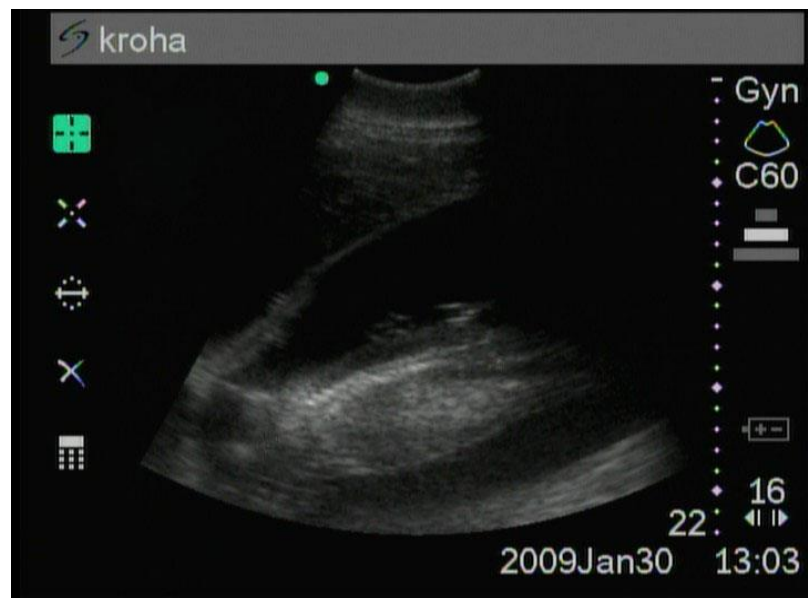

Figure 4. The 5th month of pregnancy

At the 6th month (Figure 5), the increase in head size reached $1.2 \mathrm{~cm}(5.6 \pm 0.16 \mathrm{~cm})$. Bone structures of the skull are hyperechoic due to the active mineralization of the skeleton of the fetus.

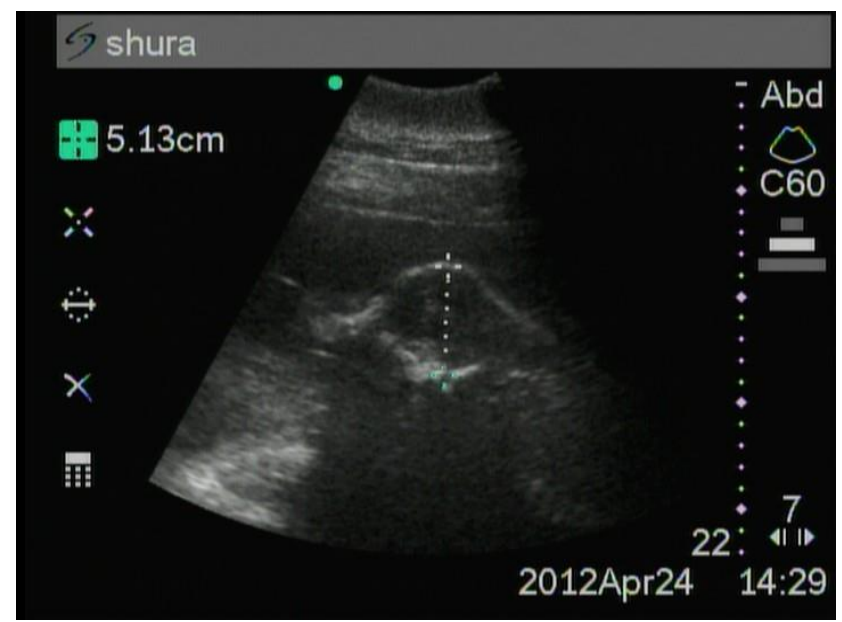

Figure 5. The 6th month of pregnancy

At the 7th month, an increase in the head to $6.4 \pm 0.21 \mathrm{~cm}$ was revealed (Figure 6).

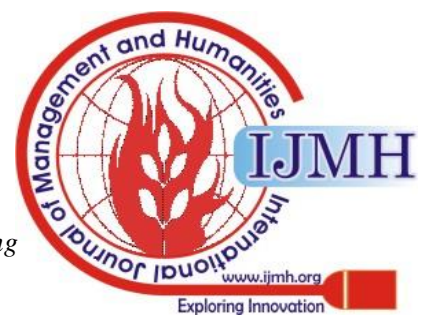

Figure 7. The 8th month of pregnancy

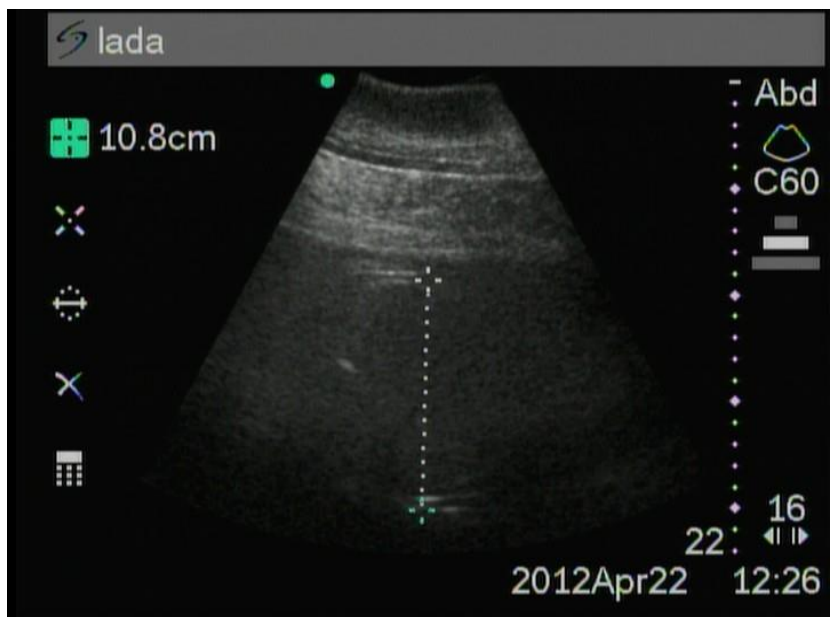

Figure 8. The 9th month of pregnancy

At the 10th month (Figure 9), the fetal head increased only by $0.7 \mathrm{~cm}$ and reached a diameter of $11.3 \pm 0.17 \mathrm{~cm}$.

At the 8th month (Figure 7), the diameter of the head es to increase significantly $(\mathrm{P}<0.001)(2.2 \mathrm{~cm})$ an (Figure 8), the increase was $2 \mathrm{~cm}$ and averaged $10.6 \pm 0.12$

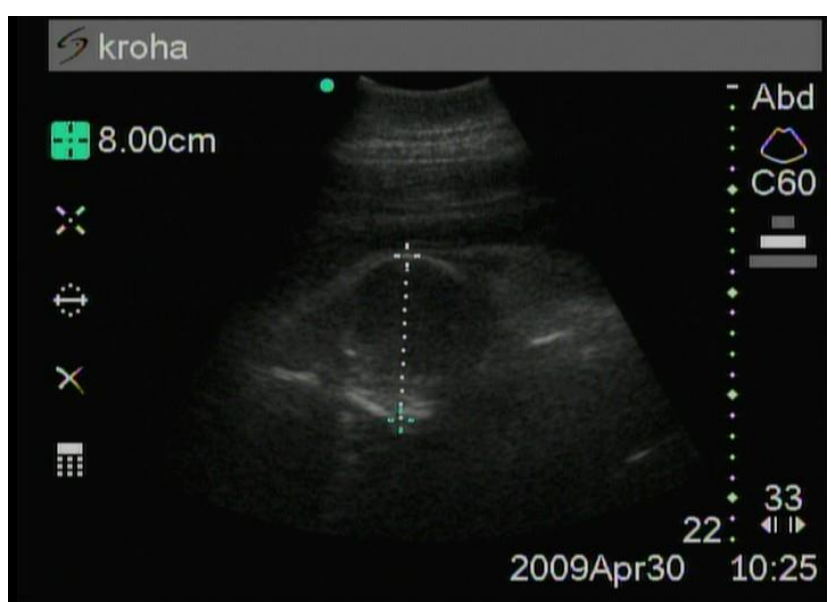




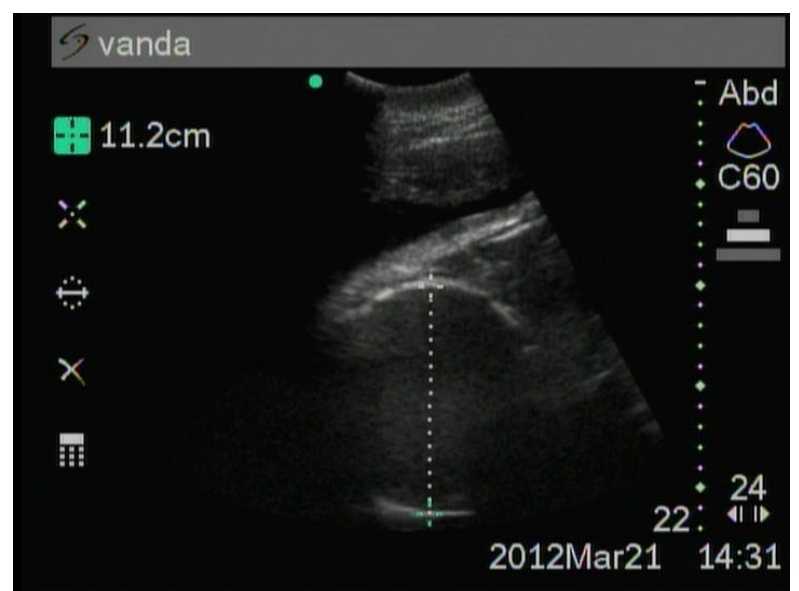

Figure 9. The 10th month of pregnancy

At the 11th month (Figure 10), the increase in head diameter was also small $(0.8 \mathrm{~cm})$ and turned out to be $12.1 \pm 0.19 \mathrm{~cm}$.

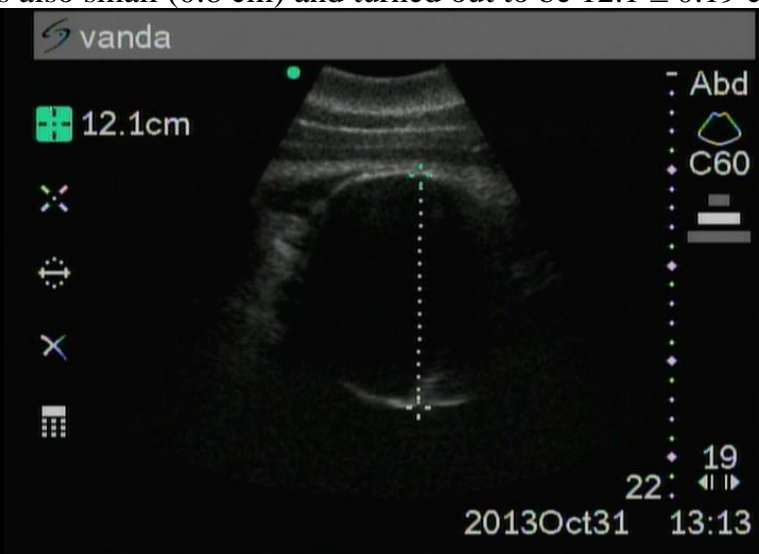

Figure 10. The 11th month of pregnancy

And, finally, in the last, 12th month of pregnancy (Figure 11), the fetal head increased by $1.7 \mathrm{~cm}$ and its diameter averaged $13.8 \pm 0.38 \mathrm{~cm}$.

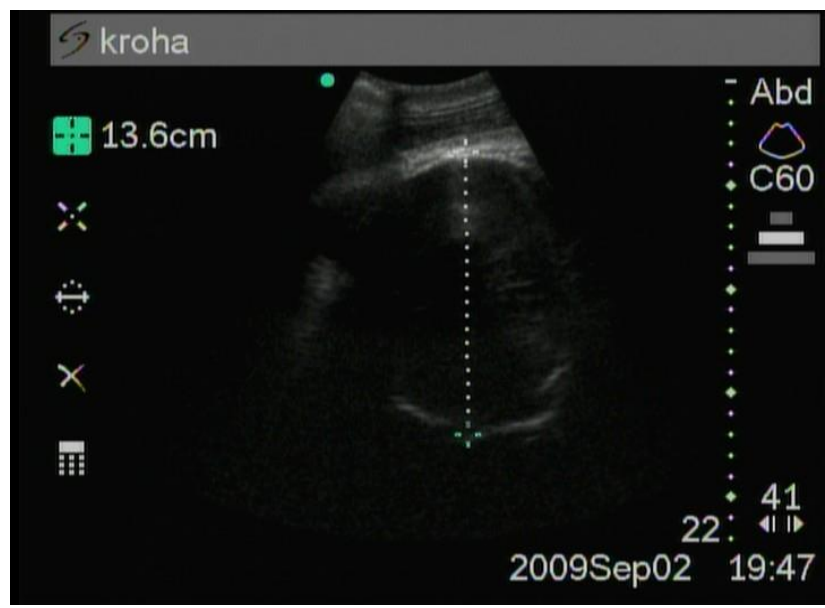

Figure 11. The 12th month of pregnancy

Thus, ifwe noted hyperechoic structures of the embryoat the 2nd month of pregnancy in the chorion cavity, then at the 3rd month we already find the fetus and placenta. The embryo becomes a fetus with a cub-like configuration. The female is already undergoing a fetal period of pregnancy, which is characterized by the rapid growth of the fetus, differentiation of tissues, the development of organs and systems from their primordia, the formation of new functional systems that provide life to the fetus in the womb and the calf after birth.

\section{RESULT ANALYSIS}

In this case, the fetal head with a diameter of $2.8 \pm$ $0.24 \mathrm{~cm}$ (table 1) was well identified as a separate anatomical formation.

Table 1.Dynamics of changes in the dorsal-ventral head size $(X \pm \mathrm{m}, \mathrm{cm})$ of the fetus during pregnancy in females of the Black Sea bottlenose dolphin

\begin{tabular}{|c|c|c|c|c|c|c|}
\hline \multirow{2}{*}{$\begin{array}{l}\text { Pregnancy } \\
\text { Month }\end{array}$} & \multicolumn{2}{|c|}{$\begin{array}{c}\text { Normal delivery } \\
\mathrm{N}=10, \mathrm{n}=22\end{array}$} & \multicolumn{2}{|c|}{$\begin{array}{l}\text { Pathological delivery } \\
\qquad N=7, n=11\end{array}$} & \multicolumn{2}{|c|}{$\begin{array}{c}\text { All deliveries } \\
\mathrm{N}=13, \mathrm{n}=33\end{array}$} \\
\hline & $\begin{array}{l}\text { Number of } \\
\text { studies }\end{array}$ & $\mathrm{X} \pm \mathrm{m}, \mathrm{cm}$ & $\begin{array}{l}\text { Number of } \\
\text { studies }\end{array}$ & $\mathrm{X} \pm \mathrm{m}, \mathrm{cm}$ & $\begin{array}{l}\text { Number of } \\
\text { studies }\end{array}$ & $\mathrm{X} \pm \mathrm{m}, \mathrm{cm}$ \\
\hline 3rd & 3 & $2,8 \pm 0,24$ & 0 & - & 3 & $2,8 \pm 0,24$ \\
\hline 4th & 3 & $3,8 \pm 0,17$ & 1 & 3,78 & 4 & $3,8 \pm 0,12 *$ \\
\hline 5th & 6 & $4,4 \pm 0,09$ & 1 & 4,41 & 7 & $4,4 \pm 0,08 * *$ \\
\hline 6th & 9 & $5,6 \pm 0,19$ & 2 & $5,8 \pm 0,10$ & 11 & $5,6 \pm 0,16 * * *$ \\
\hline 7th & 11 & $6,4 \pm 0,23$ & 1 & 6,4 & 12 & $6,4 \pm 0,21 * *$ \\
\hline 8th & 11 & $8,1 \pm 0,32$ & 3 & $10,3 \pm 1,01$ & 14 & $8,6 \pm 0,40 * * *$ \\
\hline 9th & 8 & $10,6 \pm 0,13$ & 1 & 11 & 9 & $10,6 \pm 0,12 * * *$ \\
\hline 10th & 11 & $11,3 \pm 0,22$ & 3 & $11,2 \pm 0,16$ & 14 & $11,3 \pm 0,17 * *$ \\
\hline 11th & 9 & $12,0 \pm 0,26$ & 7 & $12,2 \pm 0,31$ & 16 & $12,1 \pm 0,19 * *$ \\
\hline 12th & 7 & $13,2 \pm 0,22$ & 3 & $15,3 \pm 0,46 * * * *$ & 10 & $13,8 \pm 0,38 * *$ \\
\hline Total & 78 & & 22 & & 100 & \\
\hline
\end{tabular}

Definition of parameters:

$\mathrm{X}$ - arithmetic mean; m-standard error for the selective portion;

$\mathrm{N}$ - number of individuals examined; n-number of pregnancies studied

Significant differences between a given gestational age and a previous one: * $-\mathrm{P}<0.05$; ${ }^{* *}-\mathrm{P}<0.01$; *** $-\mathrm{P}$ $<0.001$
Significant differences between pathological and normal delivery: **** - $\mathrm{P}<0.05$

From this same table shows that, starting from the fourth month of pregnancy and ending with the twelfth, in the increase in head size there is a high degree of reliability of the differences between this gestational age and the previous one.

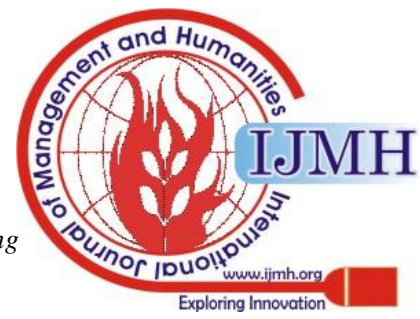


Throughout the entire period of research, there were cases of successful and unsuccessful delivery, which formed two groups of births. The individuals of the first group were safely born and live for a long time. The second group included cases when the calves were born dead or died on the first day after birth. Of particular interest was not only a comparison of the head measurements of the calves of the two groups during pregnancy, but also the blood counts of their mothers at this point in life. From table 1 it can be seen that significant differences between the size of the head at the same month of pregnancy in these two groups of bottlenose dolphins were not observed until the end of pregnancy. But at the 12th month, the fruits of dysfunctional births had a significantly $(\mathrm{P}<0.05)$ larger head diameter $(15.3 \pm 0.46 \mathrm{~cm})$ than in the group of successfully born $(13.2 \pm 0.22 \mathrm{~cm})$.

Table 2.Hematological parameters $(\mathrm{X} \pm \mathrm{m}, \mathrm{cm})$ during pregnancy in females of the Black Sea bottlenose dolphin.

\begin{tabular}{|c|c|c|c|c|c|c|}
\hline \multirow[t]{2}{*}{ Indicators } & \multicolumn{2}{|c|}{$\begin{array}{l}\text { Normaldelivery } \\
\mathrm{N}=6, \mathrm{n}=16\end{array}$} & \multicolumn{2}{|c|}{$\begin{array}{l}\text { Pathologicaldelivery } \\
\mathrm{N}=5, \mathrm{n}=8\end{array}$} & \multicolumn{2}{|c|}{$\begin{array}{l}\text { Alldeliveries } \\
\mathrm{N}=15, \mathrm{n}=30\end{array}$} \\
\hline & $\mathrm{q}$ & $\mathrm{X} \pm \mathrm{m}, \mathrm{cm}$ & $\mathrm{q}$ & $\mathrm{X} \pm \mathrm{m}, \mathrm{cm}$ & $\mathrm{q}$ & $\mathrm{X} \pm \mathrm{m}, \mathrm{cm}$ \\
\hline Age,years & 16 & $15,8 \pm 1,37$ & 8 & $11,0 \pm 1,53^{*}$ & 24 & $14,2 \pm 1,13$ \\
\hline Hemoglobin, g / l & 85 & $172,8 \pm 1,15$ & 42 & $164,5 \pm 1,70 * * *$ & 127 & $170,1 \pm 1,01$ \\
\hline Red blood cells, $\mathrm{x} 10^{12} / \mathrm{l}$ & 99 & $3,8 \pm 0,05$ & 54 & $3,8 \pm 0,05$ & 153 & $3,8 \pm 0,03$ \\
\hline White blood cells, x $10^{9}$ / l & 99 & $7,7 \pm 0,18$ & 54 & $7,3 \pm 0,30$ & 153 & $7,6 \pm 0,16$ \\
\hline Bandneutrophils,\% & 99 & $1,4 \pm 0,12$ & 54 & $2,2 \pm 0,26 *$ & 153 & $1,7 \pm 0,12$ \\
\hline Segmentedneutrophils,\% & 99 & $55,0 \pm 1,17$ & 54 & $56,0 \pm 1,22$ & 153 & $55,3 \pm 0.87$ \\
\hline Eosinophils,\% & 99 & $19,0 \pm 0,74$ & 54 & $17,7 \pm 1,10$ & 153 & $18,5 \pm 0,62$ \\
\hline Lymphocytes,\% & 99 & $20,9 \pm 0,92$ & 54 & $21,3 \pm 1,23$ & 153 & $21,1 \pm 0,74$ \\
\hline Monocytes, \% & 99 & $3,4 \pm 0,19$ & 54 & $3,0 \pm 0,29$ & 153 & $3,2 \pm 0,16$ \\
\hline $\mathrm{ESR} \mathrm{mm} / \mathrm{h}$ & 90 & $3,0 \pm 0,28$ & 52 & $3,1 \pm 0,47$ & 142 & $3,0 \pm 0,25$ \\
\hline Progesterone, ng / ml & 49 & $24,4 \pm 2,98$ & 33 & $23,4 \pm 2,47$ & 82 & $24,0 \pm 2,03$ \\
\hline Totalprotein, g / L & 72 & $69,7 \pm 0,74$ & 38 & $70,2 \pm 1,12$ & 110 & $69,9 \pm 0,62$ \\
\hline Urea, mol / L & 62 & $16,5 \pm 0,59$ & 34 & $16,2 \pm 0,67$ & 96 & $16,4 \pm 0,45$ \\
\hline Creatinine, $\mu \mathrm{mol} / \mathrm{L}$ & 68 & $128,1 \pm 3,29$ & 33 & $123,9 \pm 4,87$ & 101 & $126,7 \pm 2,72$ \\
\hline Glucose, $\mathrm{mol} / \mathrm{L}$ & 72 & $5,1 \pm 0,14$ & 35 & $4,8 \pm 0,22$ & 107 & $5,0 \pm 0,12$ \\
\hline ALT, units / l & 77 & $55,8 \pm 5,06$ & 40 & $88,5 \pm 19,77 * *$ & 117 & $67,0 \pm 7,62$ \\
\hline AST, units / l & 78 & $291,0 \pm 20,90$ & 40 & $373,3 \pm 70,67$ & 118 & $318,9 \pm 27,70$ \\
\hline GGT, units / l & 74 & $35,0 \pm 1,88$ & 37 & $37,0 \pm 2,90$ & 111 & $37,7 \pm 1,58$ \\
\hline Alkalinephosphatase,units/l & 67 & $508,5 \pm 46,41$ & 34 & $673,8 \pm 70,71$ & 101 & $564,2 \pm 39,49$ \\
\hline Iron, $\mu \mathrm{mol} / \mathrm{L}$ & 69 & $28,2 \pm 1,15$ & 41 & $26,4 \pm 1,28$ & 110 & $27,5 \pm 0,87$ \\
\hline
\end{tabular}

Definition of parameters:

$\mathrm{X}$ - arithmetic mean; $\mathrm{m}$ - standard error for the sample share; $\mathrm{N}$ - number of individuals examined;

$\mathrm{n}$ - number of pregnancies studied; $\mathrm{q}$ - number of studies Significant differences between a given gestational age and a previous one: * - $\mathrm{P}<0.05$; ** - $\mathrm{P}<0.01$; *** $-\mathrm{P}<0.001$

From table 2 it can be seen that significant differences in hematological parameters between the group of safely giving birth to females and dysfunctional giving birth are noted primarily in the concentration of hemoglobin. In safely giving birth, the amount of hemoglobin in the blood turned out to be significantly $(\mathrm{P}<0.001)$ higher $(172.8 \pm$ $1.15 \mathrm{~g} / \mathrm{l})$ than in females of the group who gave birth unsuccessfully $(164.5 \pm 1.70 \mathrm{~g} / \mathrm{l})$. At the same time, in animals of the first group, the level $(55.8 \pm 5.06 \mathrm{u} / \mathrm{l})$ of alanine transaminases (ALT) was significantly lower ( $P$ $<0.01)$ than in animals of the second group $(88.5 \pm 19.77 \mathrm{u} /$ l), which indicates the absence of toxicosis, the integrity of hepatocytes and normal liver function. Moreover, the relative content of stab neutrophils $(1.4 \pm 0.12 \%)$ was also significantly $(\mathrm{P}<0.05)$ lower than that of dysfunctional bottlenose dolphins $(2.2 \pm 0.26 \%)$, in which a more pronounced "left shift" leukoformula.

This fact indicates a greater demand in the second group of animals for phagocytosis by neutrophils of tissue fragments and the destruction of opsonized microorganisms. For other blood parameters, the difference was not significant. It can be noted that in the group of normally giving bottlenose dolphins there was a lower level (508.5 \pm $46.41 \mathrm{u} / \mathrm{l}$ ) of alkaline phosphatase (ALP) than in females of dysfunctional giving birth $(673.8 \pm 70.71 \mathrm{u} / \mathrm{l})$. However, the difference in the concentration of alkaline phosphatase, the level of which decreases with age of bottlenose dolphins from approximately 1300 to 200 units / l, rather indicates a relatively young age of dysfunctional females $(9.8 \pm 0.87$ years), which turned out to be significant $(\mathrm{P}<0,05)$ below the age of normally giving birth $(16.6 \pm 1.20$ years).

\section{CONCLUSION}

As a result of our studies, we were able to determine the gestational age in female bottlenose dolphins using their ultrasound examination in the embryonic and fetal periods, to reveal dynamic differences in the size of the fetal head during the third to twelfth months of pregnancy. These measurements had significant differences between the group of safely giving birth to females on the one hand, and dysfunctional giving birth on the other, only in the last, 12th month of pregnancy. At the same time, they revealed significant differences in hematological parameters. Trends in blood counts such as decreased hemoglobin, high alanine transaminase levels, and a large relative number of stab neutrophils can serve as markers of an unsuccessful pregnancy.

A relatively young age $(11.0 \pm 1.53$ years $)$ of dysfunctional females was revealed, which turned out to be significantly $(\mathrm{P}<0.05)$ lower than the age $(15.8 \pm 1.37$ years) of safely giving birth to dolphins.

Published By:

Blue Eyes Intelligence Engineering

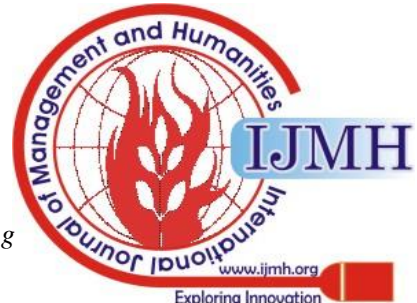


Thus, the hematological parameters of pregnant females and their age can give an objective assessment of the probability of physiologically normal delivery.

\section{REFERENCES}

1. Ozharovskaya L.V. Morphology of the reproductive system of the Black Sea bottlenose dolphin. / Black Sea bottlenose dolphin Tursiopstruncatusponticus: Morphology, physiology, acoustics, hydrodynamics / Ed. V.E. Sokolova, E.V. Romanenko. - M., Nauka, 1997. S. 102 - 113.

2. Ozharovskaya L.V. Reproduction of the Black Sea bottlenose dolphin. / Black Sea bottlenose dolphin Tursiopstruncatusponticus: Morphology, physiology, acoustics, hydrodynamics / Ed. V.E. Sokolova, E.V. Romanenko. - M., Nauka, 1997.S. 114 - 145.

3. Semenov V.A. Danilova M.N., Smyshnov A.V. Ultrasound examination in females of the Black Sea bottlenose dolphin (TursiopstruncatusponticusBarabash, 1940) during pregnancy. Collection of scientific papers based on the materials of the sixth international conference "Marine Mammals of the Holarctic". Kaliningrad, 2008.

4. Semenov V.A., Danilova M.N., Smyshnov A.V., Kozlov U.V., Osipova I.V., Vasiliev A.A., Shantiz A.U., Rodin I.A. An ultrasonic method for determining the presence and duration of pregnancy in females of the Black Sea bottlenose dolphin. / Patent for invention No. 2591730 // Registered in the State register of inventions of the Russian Federation. - M., 2016.

5. Tomilin A.G. Cetaceans // Animals of the USSR and adjacent countries. - Publishing House of the Academy of Sciences of the USSR. - 1957, T 9. - 756s.

6. Tsivtsivadze E.B. Novikova S.V. Multiple pregnancy: a modern look at the issue of pregnancy and childbirth (literature review) / Regular issues of the breast cancer, No. 1, 2014, p.16.

7. Shantz A. U. Patterns of morphogenesis of reproductive organs of male pigs in prenatal and early postnatal ontogenesis / A Yu.Shantiz. - Abstract. dis ... Dr. biol. sciences. - Krasnodar, 1999.-367 p.

8. Yablokov A.V. Whales and dolphins / A.V. Yablokov, V.M Belkovich, V.I. Borisov. - M., Science, 1972. - 472s.

9. AubinDJSt. 2001.Endocrinology. In: Dierauf LA, Gulland FMD, editors. CRC Handbook of Marine Mammal Medicine.Second Edition. Boca Raton. p 165-193.

10. Baird, D.T., and Smith, K.B., 1993, Inhibin and related peptides in the regulation of reproduction, in Oxford Review of Reproductive Biology, Milligan, S.R. (Ed.), Oxford University Press, Oxford, U.K., 191-232.

11. Bossart G D., Reidarson T H., Dierauf LA and Duffield DA.2001. Clinical Pathology. In: CRC Handbook of Marine Mammal Medicine / Dierauf L.A. and Gulland F.M.D., eds. Second Edition. Boca Raton: 593- 620

12. Brook, F., 1997, The Use of Diagnostic Ultrasound in Assessment of the Reproductive Status of the Bottlenose Dolphin, Tursiopsaduncas, in Captivity and Applications in Management of a Controlled Breeding Programme, Ph.D. thesis, Hong Kong Polytechnic University, Kowloon, Hong Kong, 339 pp.

13. Brook F, Bonn WV, and Jensen ED. 2001.Ultrasonography. In: Dierauf LA, Gulland FMD, editors. CRC Handbook of Marine Mammal Medicine.Second Edition. Boca Raton. p 593- 620.

14. Duffield, D.A., Shell, D., and Dudley, M., 2000, Demographic analysis of breeding bottlenose dolphins in North American zoological facilities: 1976-1998, in Report from the Bottlenose Dolphin Breeding Workshop, Duffield, D.A., and Robeck, T.R. (Eds.), American Zoological Association Marine Mammal Taxon Advisory Group, Silver Spring, MD, 139-156.

15. Gray K.N., Conclin R.H. Multiple births and cardiac anomalies in the bottlenosed dolphin // J. Wildlife Diseases. 1974. Vol. 10.P. 155 -157 .

16. Hendricks D.M., 1991 , Biochemistry and physiology of the gonadal hormones, in Reproduction in Domestic Animals, Cupps, P.T. (Ed.), Academic Press, San Diego, CA: 81-118.

17. Kirby, V.L., and Ridgway, S.H., 1984, Hormonal evidence of spontaneous ovulation in captive dolphins (Tursiopstruncatus and Delphinusdelphis), Rep. Int. Whaling Comm., Spec. Issue 6: 459464.

18. Lacave, G., M. Eggermont, T. Verslycke, F. Brook, A. Salbany, L. Roque and R. Kinoshita. 2004. Prediction from ultrasonographic measurements of the expected delivery date in two species of bottlenose dolphin (Tursiopstruncatus and Tursiopsaduncus).Veterinary Record 154:228-233
19. Ridgwey S.H., Benirschke K. Breeding dolphins: Present status, suggestions for the future: Final rep. to US Marine Mammals Comm. Wash. (D.C.), 1977. 308 p.

20. Robeck TR, Atkinson SKC, Brook F. 2001. Reproduction. In Dierauf LA, Gulland FMD, editors. CRC Handbook of Marine Mammal Medicine.Second Edition. Boca Raton. p 193-226.

21. Robeck TR, Schmitt TL and Osborn S. 2015. Development of predictive models for determining fetal age-at-length in belugas (Delphinapterusleucas) and their application toward in situ and ex situ population management.Marine Mammal Science. Volume 31, Issue 2, p. 591-611.

22. Sawyer-Steffan, J.E., and Kirby, V.L., 1980, A study of serum steroid hormone levels in captive female bottlenose dolphins, their correlation with reproductive status, and their application to ovulation induction in captivity, National Technical Information Service, PB80-177199, Springfield, VA.

23. Schroeder, J.P., 1990, Reproductive aspects of marine mammal., In CRC Handbook of Marine Mammal Medicine, Dierauf, L.A. (Ed.) CRC Press, Boca Raton, FL, 353-369.

24. SavelyevG.M ., Fedorov M.V., Klimenko P.A., 1991, LG Sichinava Placental insufficiency . Moscow, Medicine , 400

25. Saveliev G.M. , 1998, Ways to reduce perinatal morbidity and mortality. Bulletin of the Russian Association of Obstetricians and Gynecologists, 2 : 29-31 .

26. Semenov V.A., Danilova M.N., Shantyz A.Y., Udovichenko L.D., Smyshnov A.V. and Osipova I.V. 2016.Prenatal Ultrasound Dating in Black Sea Bottlenose Dolphins. The Aquatic Veterinarian, 10(1): 20-23.

27. Serov V., Strizhakov A.N., Markin S.A., 1997, Guidance on the Practical Obstetrics. Moscow: Medical Information Agency Ltd, 424.

28. Strizhakov A.N., Davydov A., Belotserkovtseva L.D., Ignatko I.V., 2004, Physiology and pathology of the fetus - Moscow, Medicine 356 .

29. Williamson P., Gales N.J., and Lister S., 1990, Use of real-time Bmode ultrasound for pregnancy diagnosis and measurement of fetal growth rate in captive bottlenose dolphins (Tursiopstruncatus), J. Reprod. Fertil., 88: 543-548.

\section{AUTHOR PROFILE}

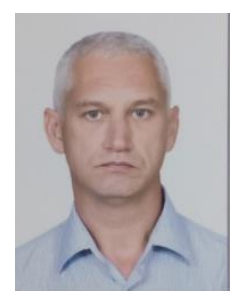

Semenov Vladimir A., In 1984 he graduated from the Kuban st State Agrarian University with a degree in animal science, where in 2002 received a diploma in Veterinary medicine. In 2005 he became candidate of veterinary Sciences. He worked from 1990 to 2015 in the Dolphinarium of Utrish. From 2015 to the present time he works in GelendzhikDolphinarium, where conducted a lot of research related to the physiological characteristics of the organism of dolphins. He is the author of more than 50 scientific articles. The theme of his candidate dissertation is "Intestinal dysbiosis in captive-adapted black sea bottlenose dolphins: Tursiops truncates ponticus".

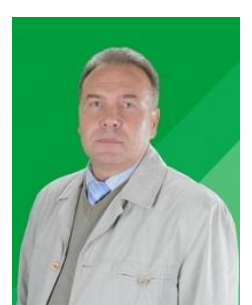

Rodin Igor A., in 1985 graduated from the Kuban State Agrarian University with a degree in veterinary and in 2002 became a doctor of veterinary sciences. The theme of his doctor dissertation is «Genetic and immunological aspects of the prevention of mastitis and interdependent endometritis in cows and diarrhea of newborn calves». Igor A. currently works in Kuban State Agrarian University as senior lecturer. Areas of interest: obstetrics and gynecology, artificial insemination, embryotransfer, surgery and so on.

His many articles were published in different journals, including foreign ones. For example his last articles are «Application of quantitative analysis of multi-component system approach for determination of ginsenosides in different mass-spectrometric conditions», „Binding action of amino-acid analogues of chloramphenicol upon the bacterial ribosome" and etc.

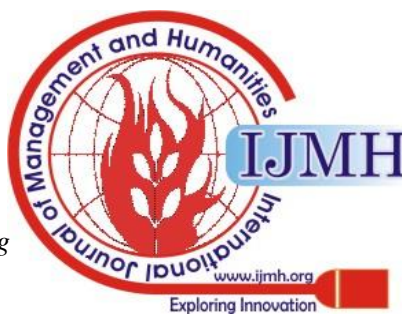

